\title{
What are the elements of the tobacco endgame?
}

\author{
George Thomson, Richard Edwards, Nick Wilson, Tony Blakely
}

Department of Public Health, University of Otago, Wellington, New Zealand

\section{Correspondence to}

George Thomson, University of Otago, Box 7343, Wellington

South, Wellington 6002, New Zealand;

george.thomson@otago.ac.nz

Received 27 February 2011 Accepted 2 August 2011

\section{ABSTRACT}

The available literature on tobacco endgames tends to be limited to discussing means, targets and difficulties. This article offers additional ideas on the key elements of endgame strategies and the circumstances in which these are likely to be adopted and implemented. We suggest such strategies will include explicit plans, will define the nature of 'the end of tobacco use/sale' and have target dates within 20 years. The likely circumstances for endgame strategy development include low (probably under 15\% adult smoking) prevalence and/or rapid prevalence reductions, wide support and strong political leadership. Even with some or all these circumstances, opposition from business, internal government forces and international factors may influence results.

\section{DEFINITION}

So as to provide a starting point for defining the tobacco 'endgame', we suggest it encapsulates both a process and a goal. In the context of health and tobacco, the former is: 'the final stage of the process of ending tobacco use'.

\section{ENDGAME THINKING TO DATE}

Researchers and policymakers have proposed endgame ideas for over a decade. ${ }^{1-7}$ One of the more sceptical comments (about phasing out cigarettes) has been that it would only be feasible:

'if smoking rates are below $5 \%$ and if the country's borders can be easily controlled. ${ }^{8}$

Despite such scepticism, recent examples of government endgame thinking include the Finnish government's adoption of the objective of ending "the use of tobacco products in Finland' Bhutanese law of 2004 aiming to end the sale of tobacco (but not the import and use). ${ }^{10} 11$ The US government has issued a report with a vision of a society free from tobacco-related death and disease', although the most optimistic outcome of the strategies would still be a smoking prevalence of $12 \%$ by $2020 .{ }^{12}$ The New Zealand government has adopted the aspirational goal of 'reducing smoking prevalence and tobacco availability to minimal levels, thereby making New Zealand essentially a smoke-free nation by $2025^{13}$ (the sale of smokeless tobacco is already banned in New Zealand). Such aspirations rely on hard won 'fundamental shifts in social norms'. ${ }^{14}$

These and other scenarios suggest that an endgame for tobacco might encompass one or more of the following: targets (eg, zero or close to zero prevalence of tobacco use), complete (or close to) ending of commercial sale of tobacco ${ }^{1} 4^{6}$ and tobacco use being fully denormalised in society, with virtually nil exposure of children to tobacco use.

\section{SOME ELEMENTS OF ENDGAME STRATEGIES}

The following elements attempt to define 'real' endgame strategies, as opposed to purely aspirational ideas. We visualise endgame strategies as a process of both planning and implementation. The process includes questions such as: how do we reach the endgame goal within the planned time period and what other things can be done now or within the planned period to help achieve the goal?

We suggest that effective government endgame strategies will have the elements of:

1. Having an explicit government intention and plan to achieve close to zero prevalence of tobacco use.

2. A clearly stated government 'end' target date within a maximum of two decades.

We suggest that a likely additional element will be mechanisms to ensure the continued and augmented availability of non-tobacco (pharmaceutical) nicotine. ${ }^{6-20}$ This will help deal with the political and ethical concerns about tobacco users needing nicotine, without creating a further significant problem of long-term nicotine use. ${ }^{21}$

As a component of having a clear plan, there is a further likely element - that government thinking has moved from an ad-hoc and incremental approach to tobacco, to the encompassing comprehensive planning that is marked by the endgames for other public health risks (smallpox, polio and hazardous products such as leaded petrol). As with them, there is likely to be international cooperation involved. ${ }^{22-24}$

\section{CIRCUMSTANCES FAVOURING ENDGAME STRATEGIES}

Endgames are most likely to be implemented in jurisdictions with 'low' prevalence and/or relatively rapid reductions in prevalence. The financial advisors Citigroup recently suggested a range of different scenarios for the tobacco industry. ${ }^{25}$ We think that the Citigroup Scenario C is likely, where a low smoking prevalence prompts a public and political 'tipping point, as (smoking) becomes increasingly unacceptable and hence easier to regulate against. ${ }^{25}$

Even without low prevalence and/or relatively rapid reductions in prevalence, effective endgame strategy adoption could occur where there is wide public understanding and support across social, ethnic and other groups of the need for an end to tobacco use. This includes the availability of survey data and other evidence of this understanding and support $\left(\mathrm{eg}^{26-31}\right)$ and good communication of this evidence to policymakers. However, we note that many factors, including opposition from vested interests, may make change difficult to achieve even with overwhelming public support. ${ }^{32-34}$ Such factors include the prevalence of use of different smoked and smokeless tobacco products and the 
relative political strengths of the tobacco companies, the tobacco control community and different parts of government. The 2010 New South Wales (Australia) legislation, banning political donations from tobacco entities, signals one direction for solutions to overcoming political opposition from the tobacco companies. ${ }^{35}$

The level at which tobacco use prevalence is low enough to stimulate real endgame planning will differ with context. We suggest that less than $15 \%$ adult tobacco use will provide situations where it is sufficiently non-normal for governments to plan for a predicted end to tobacco use. The prevalence should probably be low enough so that the questions of: (1) what tobacco-free scenario is desired (eg, what prevalence, no smoking or no tobacco products at all) and (2) how a society will reach that aim, are not academic or merely aspirational, but are discussed as realistic goals by government politicians (ie, they are on political agendas). ${ }^{36} 37$ Some jurisdictions have or are likely to soon achieve a tobacco use prevalence of less than $15 \%$ (eg, California, Canada, Sweden $)^{38-40}$ and thus may be close to the conditions for government endgame planning. Citigroup predicts that smoking will end in Sweden in 2028 and in Australia in $2030 .{ }^{41}$

Besides 'low' prevalence, it may also help if the jurisdiction has experienced a rapid decrease in prevalence. For instance, policymakers in Canada, a country with a tobacco use decrease from $30 \%$ to $18 \%$ during 1994 to 2008 , respectively, may be well placed to envisage an endgame scenario. ${ }^{42} 43$

Strong and visionary political leadership matters too. Examples of the effect of such leadership include Uruguay, where key politicians (eg, Vázquez and Muñoz) strongly supported comprehensive tobacco control ${ }^{44}$ and prevalence dropped from $32 \%$ in 2006 to $25 \%$ in $2009 .{ }^{45}{ }^{46}$ Political leadership also helped in the prevalence drop in New York City, from 22\% in 2002 to $16 \%$ in $2008 .{ }^{47}$ Such leadership could be instrumental in initiating an effective endgame strategy.

\section{DISCUSSION}

Tobacco endgame strategies represent a paradigm shift in tobacco control. In the more usual incremental approach to tobacco control, government aims are modest, and the ultimate aim is often poorly articulated. Slow progress (less than $1 \%$ absolute prevalence change a year) is far from acceptable for the readily preventable disaster that is the tobacco epidemic.

The implications of an endgame and the goals adopted may vary according to circumstances and context. For example, the effect of the option of ending commercial sales but allowing tobacco growing for personal use would vary greatly by jurisdiction (eg, due to climatic factors). There will be greater challenges in achieving endgame goals for jurisdictions with porous borders and ineffective border controls. ${ }^{6}$

The meaning of 'minimal' or 'close to zero' prevalence is and will be debated and will vary with context. Achieving a very low tobacco use prevalence, say $0.5 \%$ or less for any ethnic and social group in a society, could remove any normality within a society. However, some might argue that even this is insufficient, as this prevalence would still kill many. We note that even burdens of less than 50 readily preventable deaths a year in a jurisdiction can prompt strong government action, as well as public alarm or concern. ${ }^{48-50}$

For those who feel that relatively 'free market' economies are unlikely to effectively end the use of a widely used consumer product, many 'free market' jurisdictions have done so for a number of other hazardous commodities such as leaded petrol, various pesticides and drugs, and asbestos. ${ }^{51-54}$ For a number of these, there have been similar endgames, sharing the same elements of deliberate and detailed government planning, stated government intention and a target date. Such phased-out products have not been addictive (as is nicotine), but they usually shared the position of being supported by commercial vested interests.

A cautionary note to the quest for effective endgame strategy adoption at the national level is that tobacco policy, as for other areas, will increasingly be determined at an international level. ${ }^{55-57}$ So the balance of factors for endgames may improve if there is a strengthened Framework Convention on Tobacco Control or it may decline if there is a further increase in the relative power of international businesses over governments.

\section{CONCLUSIONS}

Tobacco endgame strategies are likely to need clear goals, plans and timetables, with sustained commitment at the government level. We look forward to fuller theories of how to achieve an endgame (ie, what measures are needed to get to zero prevalence), what will facilitate the adoption and implementation of an endgame (a political theory) and ideas on how to test them.

Acknowledgements Some of the authors (GT, NW and RE) benefited from work on a tobacco control endgame research project supported by the Marsden Fund (grant U000716). The ideas and suggestions of the reviewers were of considerable help to us.

Funding GT was supported by a Health Research Council of New Zealand (HRC) grant (the Smokefree Kids Project and the ITC Project), RE and NW by the University of Otago and TB by a HRC grant (Health Inequalities Research Programme).

Competing interests The authors have previously undertaken tobacco control work for various non-profit health sector organisations and for government and international health agencies.

Contributors All authors wrote the text.

Provenance and peer review Commissioned; externally peer reviewed.

\section{REFERENCES}

1. Gerace T. The toxic-tobacco law: "appropriate remedial action". J Public Health Policy 1999;20:394-407.

2. Daynard RA. Doing the unthinkable (and saving millions of lives). Tob Control 2009:18:2-3

3. Laugesen M, Glover M, Fraser $T$, et al. Four policies to end the sale of cigarettes and smoking tobacco in New Zealand by 2020. N Z Med J 2010:123(1314):55-65.

4. Enzi M. Enzi Introduces Bill to Wipe out Tobacco in America in a Generation. Washington: US Senate, 2007. http://enzi.senate.gov/public/index.cfm? FuseAction=NewsRoom.NewsReleases\&ContentRecord id=E04EB904-802A-23AD 4157-DD5D44E9D647 (accessed 28 Feb 2011)

5. Khoo D, Chiam Y, Ng P, et al. Phasing-out tobacco: proposal to deny access to tobacco for those born from 2000. Tob Control 2010;19:355-60.

6. Thomson G, Wilson N, Blakely T, et al. Ending appreciable tobacco use in a nation: using a sinking lid on supply. Tob Control 2010;19:431-5.

7. Beaglehole R, Bonita R, Horton R, et al. Priority actions for the non-communicable disease crisis. Lancet 2011;377:1438-47.

8. Joossens $\mathbf{L}$. Theoretically an option, but an enforcement nightmare. Tob Control 2009;18:5.

9. Ministry of Social Affairs and Health. The Aim of the Tobacco Act is to Put an End to Smoking in Finland [Finnish Government Media Release]. Helsinki: Ministry of Social Affairs and Health, 2010. http://www.stm.fi/en/pressreleases/pressrelease/ view/1522179 (accessed 8 Nov 2010).

10. Givel M. Tobacco Use Policymaking and Administration in Bhutan. Norman: The University of Oklahoma, 2009. http://works.bepress.com/cgi/viewcontent.cgi? article $=1018$ \&context $=$ michael givel (accessed 8 Nov 2011) .

11. Givel M. History of Bhutan's prohibition of cigarettes: implications for neo-prohibitionists and their critics. Int J Drug Policy 2011;22:306-10.

12. US Department of Health and Human Services. Ending the Tobacco Epidemic: $A$ Tobacco Control Strategic Action Plan for the U.S. Department of Health and Human Services. Washington DC: US Department of Health and Human Services, 2010. http://www.hhs.gov/ash/initiatives/tobacco/tobaccostrategicplan2010.pdf laccessed 8 Nov 2011)

13. New Zealand Government. Government Response to the Report of the Māori Affairs Committee on its Inquiry into the Tobacco Industry in Aotearoa and the Consequences of Tobacco Use for Māori (Final Response). Wellington: New Zealand 
Parliament, 2011. http//www parliament.nz/en-NZ/PB/Presented/Papers/8/6/0/ 49DBHOH_PAP21175_1-Government-Final-Response-to-Report-of-the-M-ori.htm.

14. Koh HK, Joossens LX, Connolly GN. Making smoking history worldwide. N Engl J Med 2007;356:1496-8.

15. Gray N, Henningfield JE, Benowitz NL, et al. Toward a comprehensive long term nicotine policy. Tob Control 2005;14:161-5.

16. Reed MB, Anderson CM, Vaughn JW, et al. The effect of over-the-counter sales of the nicotine patch and nicotine gum on smoking cessation in California. Cancer Epidemiol Biomarkers Prev 2005;14:2131-6.

17. Foley KL, Sutfin EL. Availability of tobacco cessation services in free clinics. N C Med J 2008;69:270-4

18. Sweanor DT. Policy options to reduce tobacco-caused mortality. J Addict Dis 1999;18:1-11.

19. Le Houezec J, McNeill A, Britton J. Tobacco, nicotine and harm reduction. Drug Alcohol Rev 2011;30:119-23.

20. Britton J, McNeill A. Why Britain needs a nicotine regulation authority. BMJ 2001;322:1077-8

21. Shiffman S, Sweeney CT. Ten years after the Rx-to-OTC switch of nicotine replacement therapy: what have we learned about the benefits and risks of nonprescription availability? Health Policy 2008:86:17-26.

22. Centers for Disease Control and Prevention. Vaccine preventable deaths and the Global Immunization Vision and Strategy, 2006-2015. MMWR Morb Mortal Wkly Rep 2006;55:511-15.

23. Arita I, Nakane M. Road map for polio eradication-establishing the link with Millennium Development Goal no. 4 for child survival. Jpn J Infect Dis 2008;61:169-74.

24. Henderson DA. Eradication: lessons from the past. Bull World Health Organ 1998;76(Suppl 2):17-21.

25. Fletcher N. Imperial Tobacco and BAT Fall as Citi Says Smoking Could Disappear by 2050. London: Guardian, 2011.

26. Edwards R, Wilson N, Thomson G, et al. Majority support by Maori and non-Maori smokers for many aspects of increased tobacco control regulation: national survey data. N Z Med J 2009;122(1307):115-18.

27. Edwards R, Wilson N, Weerasekera D, et al. Pacific peoples' views on major tobacco control interventions: National survey data from New Zealand. [Poster Presentation P0S3-17], in SRNT, 15th Annual Meeting 24-27 February 2010. Baltimore, Maryland, USA, 2010. http://www.wnmeds.ac.nz/academic/dph/ research/HIRP/Tobacco/posters/Edwards\%20et\%20al\%20-\%20Pacific\%20views\% 20on\%20smoking.pdf.

28. Thomson G, Wilson N, Edwards R. Kiwi support for the end of tobacco sales: New Zealand governments lag behind public support for advanced tobacco control policies. N Z Med J 2010;123(1308):106-11.

29. Trappitt R, Li J, Newcombe R. Public support for the End Game: HSC's Health and Lifestyles Survey. Health Sponsorship Council. Tobacco-free Aotearoa Conference 2010. Auckland. http://www.smokefree.co.nz/conference2010/ppts-tobacco/103.pdf (accessed 10 Nov 2010).

30. Shahab L, West R. Public support in England for a total ban on the sale of tobacco products. Tob Control 2010:19:143-7.

31. Zogby International. A Federal Ban on Cigarettes? Nationwide Survey of 1,200 Registered Voters. Zogby International for Drug Policy Alliance. New York: Utika, 2006. http://www.drugpolicy.org/docUploads/DPAZogbyTobaccoPoll2006.pdf (accessed 30 Jun 2011).

32. Dur A, Bievre D. The question of interest group influence. J Publ Pol 2007:27:1-2

33. Shapiro S, Steinzor R, Shudtz M. Regulatory Dysfunction: How Insufficient Resources, Outdated Laws, and Political Interference Cripple the 'Protector Agencies'. College Park: University of Maryland, 2009. http://digitalcommons.law.umaryland. edu/fac_pubs/878/ (accessed 30 Jun 2011).

34. Lohmann S. An information rationale for the power of special interests. Am Polit Sci Rev 1998;92:809-27.

35. New South Wales Parliament. Election Funding and Disclosures Amendment Act 2010 No 95. Sydney: New South Wales Parliament, 2010. http://www.legislation. nsw.gov.au/fragview/inforce/act $+95+2010+$ whole $+0+Y$ ?tocnav $=y$ laccessed 30 Jun 2011).

36. Sato H. Policy and politics of smoking control in Japan. Soc Sci Med 1999:49:581-600.

37. Sato H. Agenda setting for smoking control in Japan, 1945-1990: influence of the mass media on national health policy making. J Health Commun 2003;8: 23-40.

38. Reid J, Hammond D. Tobacco Use in Canada: Patterns and Trends: 2009 edition. Waterloo: University of Waterloo, 2011. http://www.tobaccoreport.ca/adtu sic sp. html (accessed 8 Feb 2011).

39. Bogdanovica I, Godfrey F, McNeill A, et al. Smoking prevalence in the European Union: a comparison of national and transnational prevalence survey methods and results. Tob Control 2011;20:e4.

40. California Department of Public Health. Adult Smoking Prevalence. Sacramento California Department of Public Health, 2010. http://www.cdph.ca.gov/programs/ tobacco/Documents/CTCPAdultSmoking_10.pdf (accessed 8 Feb 2011).

41. Cooper R. The Year Smoking Will Die Out Around the World The Telegraph. London, 2011.

42. Health Canada. A Framework for Action. Ottawa: Health Canada, 2007. http:// www.hc-sc.gc.ca/hc-ps/pubs/tobac-tabac/ffa-ca/introduction-eng.php laccessed 10 Feb 2011).

43. Health Canada. Federal Tobacco Control Strategy. Ottawa: Health Canada, 2009. http://www.hc-sc.gc.ca/hc-ps/tobac-tabac/about-apropos/role/federal/strateg-eng. php (accessed 8 Feb 2011).

44. World Health Organization. List of World No Tobacco Day Awardees. Geneva: World Health Organization, 2006. http://www.who.int/tobacco/communications/ events/wntd/2006/awards/en/index.html (accessed 23 Feb 2011).

45. World Health Organization. World Health Statistics 2010: Table 5 Risk Factors (2006 Smoking Data). Geneva: World Health Organization, 2010. http://www.who. int/gho/database/WHS2010 Part2.xls (accessed 17 Feb 2011).

46. National Institute of Statistics. Global Adult Tobacco Survey Fact Sheet Uruguay 2009. Geneva: Whorld Health organization, 2010. http://www.who.int/entity/ tobacco/surveillance/fact sheet of gats uruguay 2010.pdf laccessed 17 Feb 2011).

47. Frieden T. National public health institutes and health systems strengthening. In: IANPHI Annual Meeting, 2010. Atlanta. http://www.ianphi.org/uploads/file/ TFrieden_Opening\%20Session.pdf (accessed 17 Feb 2011).

48. Freeman B, Chapman S, Storey P. Banning smoking in cars carrying children: an analytical history of a public health advocacy campaign. Aust N Z J Public Health 2008; 32:60-5

49. Stout NA, Linn HI. Occupational injury prevention research: progress and priorities Inj Prev 2002;8(Suppl 4):IV9-14.

50. Barone M. 23 years later, L'Ambiance losses still sting. Connecticut Post Bridgeport, 2010. http://www.ctpost.com/news/article/23-years-later-L-Ambiancelosses-still-sting-460387.php (accessed 23 Feb 2011).

51. Schulberg F. United States export of products banned for domestic use. Harvard Int Law J 1979;20:331-84.

52. Smith C. Pesticide exports from U.S. ports, 1997-2000. Int J Occup Environ Health 2001;7:266-74.

53. Landrigan P. The worldwide problem of lead in petrol. Bull World Health Organ 2002;80:768

54. Birnbaum LS, Schroeder JC, Tilson HA. A repeat call for the banning of asbestos Environ Health Perspect 2010;118:A280-1.

55. Holden C, Lee K, Gilmore A, et al. Trade policy, health, and corporate influence: British American tobacco and China's accession to the World Trade Organization. In J Health Serv 2010:40:421-41.

56. Faunce TA, Townsend R. The Trans-Pacific Partnership Agreement: challenges for Australian health and medicine policies. Med J Aust 2011;194:83-6.

57. Hippert C. Multinational corporations, the politics of the world economy, and their effects on women's health in the developing world: a review. Health Care Women Int 2002:23:861-9. 